\title{
INTERMITTENT WARMING OF 'TAHITI' LIME TO PREVENT CHILLING INJURY DURING COLD STORAGE
}

\author{
Ricardo Alfredo Kluge ${ }^{1 *}$; Maria Luiza Lye Jomori ${ }^{1}$; Angelo Pedro Jacomino ${ }^{2}$; Maria Carolina \\ Dario Vitti ${ }^{1}$; Daniela Cristina Clemente Vitti ${ }^{1}$ \\ ${ }^{1}$ USP/ESALQ - Depto. de Ciências Biológicas, C.P. 9 - 13418-900 - Piracicaba, SP - Brasil. \\ ${ }^{2} U S P / E S A L Q$ - Depto. de Produção Vegetal. \\ *Corresponding author <rakluge@esalq.usp.br>
}

\begin{abstract}
Storage of 'Tahiti' limes (Citrus latifolia) at low temperature allows the marketing period to be extended. However, the loss of the green skin color and the occurrence of chilling injury (CI) prevent this extension. The purpose of this work was to verify the efficiency of intermittent warming (IW) in 'Tahiti' lime quality maintenance during cold storage. Fruit were submitted to IW $\left(20^{\circ} \mathrm{C}\right.$ for 48 hours every 7 or 14 days or $38^{\circ} \mathrm{C}$ for 24 hours every 14 days) during cold storage at $5^{\circ} \mathrm{C}$. Fruit were also stored at 5 and $10^{\circ} \mathrm{C}$ continuously. The evaluations were carried out after 30 and 60 days of storage ( +3 days of simulated marketing at $20^{\circ} \mathrm{C}$ ). $\mathrm{CI}$ occurrence on fruit was not verified after 30 days of storage. However, after 60 days of storage $60 \%$ of the fruit kept continuously at $5^{\circ} \mathrm{C}$ presented CI, while fruit intermittently warmed had 10 to $12.5 \%$ CI. Fruit stored at $10^{\circ} \mathrm{C}$ did not present $\mathrm{CI}$, but they showed high degreening after 30 days of storage. Fruit warmed at $38^{\circ} \mathrm{C}$ for 24 hours every 14 days developed rot, loss of green skin color and vitamin $\mathrm{C}$, high respiratory rates, as well as high levels of ethanol and acetaldehyde in the juice. Fruit can be stored at $5^{\circ} \mathrm{C}$ during 30 days, without risk of CI, while IW can be used to reduce CI after 60 days of storage.
\end{abstract}

Key words: Citrus latifolia, chilling injury, ethanol, acetaldehyde, degreening

\section{AQUECIMENTO INTERMITENTE DE LIMA 'TAHITI' PARA PREVENIR INJÚRIAS PELO FRIO DURANTE O ARMAZENAMENTO REFRIGERADO}

\begin{abstract}
RESUMO: A conservação refrigerada da lima ácida 'Tahiti' (Citrus latifolia) sob baixa temperatura permite o aumento no período de comercialização dos frutos, entretanto, a perda da coloração verde da casca e a incidência de injúrias pelo frio impedem este prolongamento. O objetivo do presente experimento foi verificar a eficiência do aquecimento intermitente na manutenção da qualidade de lima ácida 'Tahiti' durante o armazenamento refrigerado. Os frutos foram submetidos ao aquecimento intermitente $\left(20^{\circ} \mathrm{C}\right.$ por 48 horas a cada 7 ou 14 dias ou a $38^{\circ} \mathrm{C}$ a cada 14 dias) durante o armazenamento a $5^{\circ} \mathrm{C}$. O armazenamento contínuo foi realizado a 5 e $10^{\circ} \mathrm{C}$. As avaliações foram realizadas após 30 e 60 dias de armazenamento (+ 3 dias de comercialização simulada a $20^{\circ} \mathrm{C}$ ). Não foi verificada ocorrência de injúrias pelo frio após 30 dias de armazenamento. Entretanto, após 60 dias de estocagem, $60 \%$ dos frutos armazenados continuamente a $5^{\circ} \mathrm{C}$ apresentaram injúrias pelo frio, enquanto que em frutos que sofreram aquecimento intermitente apresentaram de 10 a $12,5 \%$ de injúrias pelo frio. Frutos armazenados a $10^{\circ} \mathrm{C}$ não apresentaram injúrias pelo frio, mas apresentaram desverdecimento após 30 dias de armazenamento. Aquecimento dos frutos a $38^{\circ} \mathrm{C}$ por 24 horas a cada 14 dias causou podridão, perda de coloração e vitamina $\mathrm{C}$, alta taxa respiratória e altos níveis de etanol e acetaldeído. Lima 'Tahiti' pode ser armazenada durante 30 dias a $5^{\circ} \mathrm{C}$ sem apresentar injúrias pelo frio, enquanto o aquecimento intermitente reduz a incidência de injúrias após 60 dias de conservação.

Palavras-chave: Citrus latifolia, injurias pelo frio, etanol, acetaldeído, desverdecimento
\end{abstract}

\section{INTRODUCTION}

Chilling injury (CI) is a disorder of crops of tropical and subtropical origin, although certain physiological disorders also appear in temperate crops, only when they are stored at low temperatures. CI is not the same as freezing injury, which is a result of the damage from ice crystals formed in tissues stored below their freezing point. The minimum safe temperature for chilling sensi- tive commodities is above their freezing point. The critical temperature for CI varies with the commodity, but it generally occurs when storage is made at temperatures below $10-13^{\circ} \mathrm{C}$. Therefore, crops which are susceptible to CI often have a short storage life since low temperatures cannot be used to delay deterioration and pathogen growth.

The primary cause of $\mathrm{CI}$ in fruits is through the damage of cell membranes. Membrane damage causes a 
cascade of secondary reactions, which may include ethylene production, increase of respiration, accumulation of toxic compounds and alteration of the cellular structure (Shewfelt, 1993). The appearance of CI depends not only on the storage temperature but also on the length of exposure. If the product is stored below the critical temperature for short periods, the fruit can repair the damage. If the exposure is prolonged, irreversible damage occurs and visible symptoms often appear. The injury occurs sooner and it is more severe when the temperature is below the threshold temperature. Detection and diagnosis of CI is difficult, since products often have a healthy aspect when removed from the chilling temperature, and symptoms occur when they return to higher temperatures (Wang, 1993).

The best storage conditions for the 'Tahiti' lime are for temperatures ranging from 10 to $12^{\circ} \mathrm{C}$ and relative humidity from 85 to $95 \%$. Under such conditions, fruit can be stored for four to eight weeks. Long periods of temperatures below $8^{\circ} \mathrm{C}$ induce $\mathrm{CI}$ in fruit, characterized by superficial pitting and an increase of rot incidence (Chitarra \& Chitarra, 1990; Kader \& Arpaia, 1992; Kluge et al., 2001).

Additional treatments for chilling storage of fruit and vegetables have the objective of extending the storage period and marketing. Such treatments include intermittent warming (IW), which consists of exposing fruits to one or more periods of high temperature during the cold storage (Wang, 1993). IW increases fruit resistance to low temperatures, enabling them to be stored under temperatures below those normally recommended (Kluge et al., 2001). In this way, greater benefits are achieved concerning the use of cold temperatures by keeping product quality during storage. Beneficial effects of IW were observed for several fruit, such as tomatoes (Artés \& Escriche, 1994; Kluge et al., 1998b), cucumbers and zucchinis (Wang, 1993), peaches (Kluge et al., 1996), plums (Kluge et al., 1997), eggplants, okras and sweet peppers (Kluge et al., 1998a). Cohen et al. (1983), Cohen (1988) and Artés et al. (1993) tested IW for lemons (Citrus limon Burn.), and found considerable improvement of the fruit conservation period, due to CI reduction. On the other hand, the maintenance of the skin green color of the 'Tahiti' lime fruit (Citrus latifolia, Tanaka) is desirable during storage and commercialization. As the green color fades, the fruit acceptance by the market is gradually reduced. In practice, the 'Tahiti' lime is harvested when showing green color, after reaching full development, and commercialized while the skin is still green. However, the chlorophyll degradation processes and carotenoid synthesis continue under room temperature conditions during marketing, and end up causing green color loss (Sinclair, 1984; Baldwin, 1994). This also happens when fruits are kept under refrigeration, although in this case the degreening speed decreases.
The purpose of the present study was to investigate the effect of IW on the storability of the 'Tahiti' lime to prevent CI during cold storage.

\section{MATERIAL AND METHODS}

The 'Tahiti' acid lime fruit used in this work came from a commercial orchard located in Moji-Mirim, SP, Brazil $\left(22^{\circ} 25^{\prime} 55^{\prime}\right.$ 'S , 46 $57^{\circ} 28^{\prime \prime} \mathrm{W}$, and altitude of 640 $\mathrm{m})$. The orchard trees were in 8-yr old 2001, managed traditionally in terms of soil, irrigation, nutrient and disease control. Fruit were selected according to size $(50 \mathrm{~mm}$ diameter, $\pm 3 \mathrm{~mm}$ ) and color (intense green). They were divided into five lots, one stored uninterruptedly at $10^{\circ} \mathrm{C}$; the second stored uninterruptedly at $5^{\circ} \mathrm{C}$, the third intermittently warmed to $20^{\circ} \mathrm{C}$ for 48 hours every seventh day of storage at $5^{\circ} \mathrm{C}$; the fourth submitted to warming at $20^{\circ} \mathrm{C}$ for 48 hours every $14^{\text {th }}$ day of storage at $5^{\circ} \mathrm{C}$, and the fifth submitted to warming at $38^{\circ} \mathrm{C}$ for 24 hours every $14^{\text {th }}$ day of storage at $5^{\circ} \mathrm{C}$. These warming procedures consisted in transferring the fruit from storage at $5^{\circ} \mathrm{C}$ to chambers set at the respective temperatures.

Fruitw ere evaluated affer 30 and 60 days of storage (+ three days of sim ulated $m$ arketing period at $20^{\circ} \mathrm{C}$ ). CI was taken as the percentage of affected fruit and CI using five categories, according to the affected surface area, as follows: $0=0 \%, 1<5 \%, 2=5-25 \%, 3=25-50 \%$ and $4=>50 \%$. The skin color was evaluated through a Minolta Chroma Meter CR-300, which provided measurements of the hue angle $\left(\mathrm{h}^{\circ}\right)$ and chroma $\left(\mathrm{C}^{*}\right)$. Weight loss $(\%)$ was determined considering the fresh weight at harvest and after three more days at $20^{\circ} \mathrm{C}$. To measure the respiratory rate, five fruits of each treatment were placed for three hours in 3-L hermetic glass jars. A rubber septum was placed on each lid, through which gas samples were taken. A sample from each pot was collected with the aid of a 1-mL syringe and then analyzed through a $\mathrm{CO}_{2}$ and $\mathrm{O}_{2}$ analyzer. Soluble solids content (SSC) ${ }^{\circ}$ Brix, titratable acidity (TA) $\%$, and vitamin $\mathrm{C}$ level, $\mathrm{mg}$ of ascorbic acid per $100 \mathrm{~mL}$ of juice were also measured. The technological index (TI) was found through the equation T.I. $=($ TSS $\times \%$ juice $) /$ 100. Ethanol and acetaldehyde were determined by juice head-space analysis by gas chromatography as described by Cohen et al. (1990).

Analysis of variance was performed using SANEST software (Zonta \& Machado, 1984) according to a completely randomized design. Mean comparisons were performed by Tukey test at $P \leq 0.05$.

\section{RESULTS AND DISCUSSION}

Fruit kept at $10^{\circ} \mathrm{C}$ did not present CI during storage (Table 1). In addition, no visible symptoms of CI were observed in fruit of other treatments after 30 days of storage. $\mathrm{CI}$ of fruit stored at $5^{\circ} \mathrm{C}$ was observed only after 60 
days of storage (Table 1) and symptoms were visible only after the chilled fruit was removed from the cold storage to $20^{\circ} \mathrm{C}$. In this period, CI was characterized by small black superficial pits on the skin. The incidence of $\mathrm{CI}$ was $60 \%$ for fruit kept continually at $5^{\circ} \mathrm{C}$, while fruit intermittently warmed presented 10 to $12.5 \%$ of CI. Fruit warmed for 24 hours at $38^{\circ} \mathrm{C}$ every 14 days did not presented CI, but fruit presented high rot development caused by Penicillium digitatum.

In relation to the green skin color, fruit kept at $10^{\circ} \mathrm{C}$ had greater losses as compared to those stored at $5^{\circ} \mathrm{C}$ (Table 2). Such results were expected, considering that the speed of metabolic reactions is directly related to the temperature at which it occurs. Thus, fruit stored at $10^{\circ} \mathrm{C}$ had the lowest hue angle $\left(\mathrm{h}^{\circ}\right)$, that is, they were less green. Hue angles deviating more from $90^{\circ}$ represent greener fruit, whereas values closer to $90^{\circ}$, yellower fruit. Chroma defines the color intensity, presenting values around zero for neutral colors (gray) and values around 60 for bright colors (McGuire, 1992). In this way, as for the present work, higher chroma values mean higher yellow color intensity.
In relation to weight loss, of storage no differences were observed among treatments after 30 days (Table 3). However, fruit submitted to IW for 24 hours at $38^{\circ} \mathrm{C}$ every 14 days had the highest weight loss after 30 and 60 days of storage. On the other hand, fruit kept continuously at $10^{\circ} \mathrm{C}$ had the lowest weight loss after 60 days of storage. This highest weight loss was due the high temperature, leading to a high metabolism rate, considering that the metabolic reaction (transpiration, in the case) speed is directly related to temperature.

After 30 days of storage, the respiratory rate was higher for fruit stored at $10^{\circ} \mathrm{C}$ than for those stored at $5^{\circ} \mathrm{C}$ or intermittently warmed, with exception to fruit submitted to IW for 24 hours at $38^{\circ} \mathrm{C}$ every 14 days which presented similar respiratory rates (Table 4). After 60 days, the respiration of these last fruits was also high, while for the other treatments a drop in the respiratory rate was verified. This decline in respiration from 30 to 60 days is due to the fact that the lime is a non-climacteric fruit, and frequently presents a constant reduction on respiratory rate after harvest, considering the low production of ethylene and absence of stored starch.

Table 1 - Percentage of chilling injury for 'Tahiti' lime after 60 days of storage at different temperatures $\left(+3 \text { days at } 20^{\circ} \mathrm{C}\right)^{1}$.

\begin{tabular}{|c|c|c|c|c|c|c|}
\hline \multirow[b]{2}{*}{ Storage temperature } & \multirow{2}{*}{$\begin{array}{l}\text { Affected fruit } \\
(\%)\end{array}$} & \multicolumn{5}{|c|}{ Category } \\
\hline & & $\begin{array}{c}0 \\
(0 \%) \\
\end{array}$ & $\begin{array}{c}1 \\
(0-5 \%)\end{array}$ & $\begin{array}{c}2 \\
(5-25 \%) \\
\end{array}$ & $\begin{array}{c}3 \\
(25-50 \%) \\
\end{array}$ & $\begin{array}{c}4 \\
(>50 \%)\end{array}$ \\
\hline & & \multicolumn{5}{|c|}{$\%$ of fruit } \\
\hline $10^{\circ} \mathrm{C}$ continuously & $0.0 \mathrm{c}$ & $0.0 \mathrm{c}$ & $0.0 \mathrm{c}$ & 0.0 & 0.0 & 0.0 \\
\hline $5^{\circ} \mathrm{C}$ continuously & $60.0 \mathrm{a}$ & $40.0 \mathrm{~b}$ & $45.0 \mathrm{a}$ & 15.0 & 0.0 & 0.0 \\
\hline $5^{\circ} \mathrm{C}+\mathrm{IW}-1^{2}$ & $12.5 \mathrm{~b}$ & $87.5 \mathrm{a}$ & $12.5 \mathrm{~b}$ & 0.0 & 0.0 & 0.0 \\
\hline $5^{\circ} \mathrm{C}+\mathrm{IW}-2$ & $10.0 \mathrm{~b}$ & $90.0 \mathrm{a}$ & $10.0 \mathrm{~b}$ & 0.0 & 0.0 & 0.0 \\
\hline $5^{\circ} \mathrm{C}+\mathrm{IW}-3$ & $0.0 \mathrm{c}$ & $0.0 \mathrm{c}$ & $0.0 \mathrm{c}$ & 0.0 & 0.0 & 0.0 \\
\hline F test & $* *$ & $*$ & $* *$ & - & - & - \\
\hline
\end{tabular}

Table 2 - Hue angle $\left(\mathrm{h}^{\circ}\right)$ and chroma for 'Tahiti' lime after 30 and 60 days of storage at different temperatures and intermittent warming $\left(+3 \text { days at } 20^{\circ} \mathrm{C}\right)^{1}$.

\begin{tabular}{|c|c|c|c|c|}
\hline \multirow{2}{*}{ Storage temperature } & \multicolumn{4}{|c|}{ Skin color } \\
\hline & 30 days & 60 days & 30 days & 60 days \\
\hline \multicolumn{5}{|c|}{ - } \\
\hline $10^{\circ} \mathrm{C}$ continuously & $120.27 \mathrm{c}$ & $103.87 \mathrm{c}$ & 39.99 a & $54.78 \mathrm{a}$ \\
\hline $5^{\circ} \mathrm{C}$ continuously & $131.22 \mathrm{a}$ & $120.70 \mathrm{a}$ & $32.48 \mathrm{bc}$ & $42.80 \mathrm{~b}$ \\
\hline $5^{\circ} \mathrm{C}+\mathrm{IW}-1^{2}$ & $131.60 \mathrm{a}$ & $119.52 \mathrm{ab}$ & $121.97 \mathrm{bc}$ & $42.39 \mathrm{~b}$ \\
\hline $5^{\circ} \mathrm{C}+\mathrm{IW}-2$ & 130.09 a & $121.90 \mathrm{a}$ & $29.76 \mathrm{c}$ & $43.79 \mathrm{~b}$ \\
\hline $5^{\circ} \mathrm{C}+\mathrm{IW}-3$ & $125.99 \mathrm{~b}$ & $117.89 \mathrm{~b}$ & $33.98 \mathrm{~b}$ & $45.11 \mathrm{~b}$ \\
\hline F test & $* *$ & $* *$ & $* *$ & $*$ \\
\hline
\end{tabular}


In relation to ethanol and acetaldehyde contents, fruit submitted to IW for 24 hours at $38^{\circ} \mathrm{C}$ every 14 days showed alterations in the respiratory metabolism, with higher levels of products from fermentation in relation to fruit of the remaining treatments (Table 5). Yet, informal sensorial analysis evidenced the presence of odd smells, produced by the fermentative process in the fruit. Therefore, this IW regime was too drastic, affecting fruit quality. Considering the other treatments, the ethanol and acetaldehyde amounts were similar.

In general, no differences were observed in the physicochemical characteristics among treatments in which fruit were submitted to IW at $20^{\circ} \mathrm{C}$ for 48 hours every 14 or 7 days, as well as those stored at $5^{\circ} \mathrm{C}$ continuously (Table 6). However, fruit submitted to IW for 24 hours at $38^{\circ} \mathrm{C}$ every 14 days presented a reduction in the titratable acidity during storage and lowest juice percentage after 60 days of storage. The lower titratable acid-

Table 3 - Weight loss for 'Tahiti' lime after 30 and 60 days of storage at different temperatures and intermittent warming $\left(+3 \text { days at } 20^{\circ} \mathrm{C}\right)^{1}$.

\begin{tabular}{lcc}
\hline \multirow{2}{*}{ Storage temperature } & \multicolumn{2}{c}{ Weight loss $(\%)$} \\
\cline { 2 - 3 } & 30 days & 60 days \\
\hline $10^{\circ} \mathrm{C}$ continuously & $5.61 \mathrm{~b}$ & $6.67 \mathrm{c}$ \\
$5^{\circ} \mathrm{C}$ continuously & $5.34 \mathrm{~b}$ & $10.45 \mathrm{~b}$ \\
$5^{\circ} \mathrm{C}+\mathrm{IW}-1^{2}$ & $5.56 \mathrm{~b}$ & $9.89 \mathrm{~b}$ \\
$5^{\circ} \mathrm{C}+\mathrm{IW}-2$ & $5.39 \mathrm{~b}$ & $10.06 \mathrm{~b}$ \\
$5^{\circ} \mathrm{C}+\mathrm{IW}-3$ & $8.03 \mathrm{a}$ & $16.14 \mathrm{a}$ \\
\hline $\mathrm{F}$ test & $* *$ & $* *$
\end{tabular}

${ }^{1}$ Mean separation in column by the Tukey test at $P \leq 0.05$

${ }^{2} \mathrm{IW}-1$, intermittent warming at $20^{\circ} \mathrm{C}$ for 48 hours every 7 days and storage at $5^{\circ} \mathrm{C}$; IW-2, intermittent warming at $20^{\circ} \mathrm{C}$ for 48 hours every 14 days and storage at $5^{\circ} \mathrm{C}, \mathrm{AI}-3$, intermittent warming at $38^{\circ} \mathrm{C}$ for 24 hours every 14 days and storage at $5^{\circ} \mathrm{C}$.

${ }^{* *}$ F test significant at $P \leq 0.01$. ity caused reduction of the technological index of these fruits. This represents a disadvantage in relation to fruit quality for the industry. They also suffered vitamin $\mathrm{C}$ loss, representing a reduction in nutritional quality.

IW was effective to reduce CI in several citrus cultivars (Artés, 1995). Cohen et al. (1983) have demonstrated that the occurrence of peel pitting in 'Villa Franca' lemons after 4-5 months of storage at $2^{\circ} \mathrm{C}$ was $54-59 \%$. Fruit warmed at $13^{\circ} \mathrm{C}$ for 7 days after each 21-day periods reduced this percentage to $3-4 \%$. This treatment for lemons stored at $2^{\circ} \mathrm{C}$ with warming to $13^{\circ} \mathrm{C}$ has been used as a commercial method in Israel for storage during periods higher than 6 months (Cohen, 1988). Schirra \& Cohen (1999) have verified for 'Olinda' orange that IW during storage, with cycles of 3 weeks at $3^{\circ} \mathrm{C}$ by 2 weeks at $15^{\circ} \mathrm{C}$ delayed the onset of $\mathrm{CI}$ by approximately 10 weeks regarding storage continuously at $3^{\circ} \mathrm{C}$ and greatly enhanced resistance of CI development. Investigations on

Table 4 - Respiratory rate for 'Tahiti' lime after 30 and 60 days of storage at different temperatures and intermittent warming $\left(+3 \text { days at } 20^{\circ} \mathrm{C}\right)^{1}$.

\begin{tabular}{lcc}
\hline \multirow{2}{*}{ Storage temperature } & \multicolumn{2}{c}{ Respiratory rate $\left(\mathrm{mL} \mathrm{CO}_{2} \mathrm{~kg}^{-1} \mathrm{~h}^{-1}\right)$} \\
\cline { 2 - 3 } & 30 days & 60 days \\
\hline $10^{\circ} \mathrm{C}$ continuously & $15.41 \mathrm{a}$ & $7.71 \mathrm{~b}$ \\
$5^{\circ} \mathrm{C}$ continuously & $13.00 \mathrm{bc}$ & $5.28 \mathrm{c}$ \\
$5^{\circ} \mathrm{C}+\mathrm{IW}-1^{2}$ & $12.81 \mathrm{~cd}$ & $5.38 \mathrm{c}$ \\
$5^{\circ} \mathrm{C}+\mathrm{IW}-2$ & $11.59 \mathrm{~d}$ & $5.66 \mathrm{c}$ \\
$5^{\circ} \mathrm{C}+\mathrm{IW}-3$ & $15.09 \mathrm{ab}$ & $14.20 \mathrm{a}$ \\
\hline $\mathrm{F}$ test & $* *$ & $* *$
\end{tabular}

${ }^{1}$ Mean separation in column by the Tukey test at $P \leq 0.05$

${ }^{2} \mathrm{IW}-1$, intermittent warming at $20^{\circ} \mathrm{C}$ for 48 hours every 7 days and storage at $5^{\circ} \mathrm{C}$; IW-2, intermittent warming at $20^{\circ} \mathrm{C}$ for 48 hours every 14 days and storage at $5^{\circ} \mathrm{C}, \mathrm{AI}-3$, intermittent warming at $38^{\circ} \mathrm{C}$ for 24 hours every 14 days and storage at $5^{\circ} \mathrm{C}$.

${ }^{* * *}$ F test significant at $P \leq 0.01$.

Table 5 - Ethanol and acetaldehyde amounts for 'Tahiti' lime after 30 and 60 days of storage at different temperatures and intermittent warming $\left(+3 \text { days at } 20^{\circ} \mathrm{C}\right)^{1}$.

\begin{tabular}{lcccc}
\hline \multirow{2}{*}{ Storage temperature } & \multicolumn{2}{c}{ Ethanol } & \multicolumn{2}{c}{ Acetaldehyde } \\
\cline { 2 - 5 } & 30 days & 60 days & 30 days & 60 days \\
\hline & $90.03 \mathrm{~b}$ & $121.34 \mathrm{~b}$ & $9.34 \mathrm{~b}$ & $14.06 \mathrm{~b}$ \\
$10^{\circ} \mathrm{C}$ continuously & $95.66 \mathrm{~b}$ & $123.09 \mathrm{~b}$ & $8.67 \mathrm{~b}$ & $14.00 \mathrm{~b}$ \\
$5^{\circ} \mathrm{C}$ continuously & $96.00 \mathrm{~b}$ & $92.13 \mathrm{~b}$ & $6.67 \mathrm{~b}$ & $11.09 \mathrm{~b}$ \\
$5^{\circ} \mathrm{C}+\mathrm{IW}-1^{2}$ & $78.33 \mathrm{~b}$ & $94.44 \mathrm{~b}$ & $7.00 \mathrm{~b}$ & $15.00 \mathrm{~b}$ \\
$5^{\circ} \mathrm{C}+\mathrm{IW}-2$ & $356.23 \mathrm{a}$ & $334.17 \mathrm{a}$ & $32.33 \mathrm{a}$ & $21.02 \mathrm{a}$ \\
$5^{\circ} \mathrm{C}+\mathrm{IW}-3$ & $* *$ & $* *$ & $* *$ & $* *$ \\
\hline $\mathrm{F}$ test & &
\end{tabular}

${ }^{1}$ Mean separation in column by the Tukey test at $P \leq 0.05$

${ }^{2} \mathrm{IW}-1$, intermittent warming at $20^{\circ} \mathrm{C}$ for 48 hours every 7 days and storage at $5^{\circ} \mathrm{C}$; IW-2, intermittent warming at $20^{\circ} \mathrm{C}$ for 48 hours every 14 days and storage at $5^{\circ} \mathrm{C}, \mathrm{AI}-3$, intermittent warming at $38^{\circ} \mathrm{C}$ for 24 hours every 14 days and storage at $5^{\circ} \mathrm{C}$.

${ }^{* *} \mathrm{~F}$ test significant at $P \leq 0.01$. 
Table 6 - Soluble solids content (SSC), titratable acidity (TA), juice percentage, technological index (TI) and ascorbic acid amount of 'Tahiti' lime after 30 and 60 days of storage at different temperatures $(+3$ days at $\left.20^{\circ} \mathrm{C}\right)^{1}$.

\begin{tabular}{|c|c|c|}
\hline Storage temperature & 30 days & 60 days \\
\hline & \multicolumn{2}{|c|}{ SSC $\left({ }^{\circ}\right.$ Brix $)$} \\
\hline $10^{\circ} \mathrm{C}$ continuously & 8.20 & 7.70 \\
\hline $5^{\circ} \mathrm{C}$ continuously & 8.44 & 7.55 \\
\hline $5^{\circ} \mathrm{C}+\mathrm{IW}-12$ & 8.26 & 8.00 \\
\hline $5^{\circ} \mathrm{C}+\mathrm{IW}-2$ & 8.21 & 7.37 \\
\hline $5 \circ C+I W-3$ & 8.36 & 7.52 \\
\hline \multirow[t]{2}{*}{$\mathrm{F}$ test } & ns & ns \\
\hline & \multicolumn{2}{|c|}{ TA $(\%$ citric acid $)$} \\
\hline $10^{\circ} \mathrm{C}$ continuously & $6.36 \mathrm{a}$ & $5.73 \mathrm{a}$ \\
\hline $5^{\circ} \mathrm{C}$ continuously & $6.37 \mathrm{a}$ & $5.25 \mathrm{a}$ \\
\hline $5^{\circ} \mathrm{C}+\mathrm{IW}-1$ & $6.86 \mathrm{a}$ & $5.76 \mathrm{a}$ \\
\hline $5^{\circ} \mathrm{C}+\mathrm{IW}-2$ & $6.33 \mathrm{a}$ & $5.62 \mathrm{a}$ \\
\hline $5^{\circ} \mathrm{C}+\mathrm{IW}-3$ & $5.51 \mathrm{~b}$ & $3.99 \mathrm{~b}$ \\
\hline \multirow[t]{2}{*}{$\mathrm{F}$ test } & $*$ & $* *$ \\
\hline & \multicolumn{2}{|c|}{ Juice percentage } \\
\hline $10^{\circ} \mathrm{C}$ continuously & 45.38 & $47.75 \mathrm{a}$ \\
\hline $5^{\circ} \mathrm{C}$ continuously & 42.88 & $43.51 \mathrm{a}$ \\
\hline $5^{\circ} \mathrm{C}+\mathrm{IW}-1$ & 40.55 & $45.18 \mathrm{a}$ \\
\hline $5^{\circ} \mathrm{C}+\mathrm{IW}-2$ & 39.71 & $50.35 \mathrm{~b}$ \\
\hline $5^{\circ} \mathrm{C}+\mathrm{IW}-3$ & 36.25 & 27.13 \\
\hline \multirow[t]{2}{*}{ F test } & ns & $*$ \\
\hline & \multicolumn{2}{|c|}{ TI [(TSS x \% juice $) / 100]$} \\
\hline $10^{\circ} \mathrm{C}$ continuously & $3.76 \mathrm{a}$ & $3.70 \mathrm{a}$ \\
\hline $5^{\circ} \mathrm{C}$ continuously & $3.62 \mathrm{a}$ & $3.21 \mathrm{a}$ \\
\hline $5^{\circ} \mathrm{C}+\mathrm{IW}-1$ & $3.34 \mathrm{a}$ & $3.62 \mathrm{a}$ \\
\hline $5^{\circ} \mathrm{C}+\mathrm{IW}-2$ & $3.25 \mathrm{a}$ & $3.86 \mathrm{a}$ \\
\hline $5^{\circ} \mathrm{C}+\mathrm{IW}-3$ & $3.04 \mathrm{~b}$ & $2.05 \mathrm{~b}$ \\
\hline \multirow[t]{2}{*}{ F test } & $*$ & $* *$ \\
\hline & \multicolumn{2}{|c|}{ Ascorbic acid $\left(\mathrm{mg} 100 \mathrm{~mL}^{-1}\right)$} \\
\hline $10^{\circ} \mathrm{C}$ continuously & $28.77 \mathrm{a}$ & $24.14 \mathrm{a}$ \\
\hline $5^{\circ} \mathrm{C}$ continuously & $27.40 \mathrm{a}$ & $21.66 \mathrm{a}$ \\
\hline $5^{\circ} \mathrm{C}+\mathrm{IW}-1$ & 30.19 a & $22.94 \mathrm{a}$ \\
\hline $5^{\circ} \mathrm{C}+\mathrm{IW}-2$ & $29.66 \mathrm{a}$ & $20.84 \mathrm{a}$ \\
\hline $5^{\circ} \mathrm{C}+\mathrm{IW}-3$ & $20.21 \mathrm{~b}$ & $12.90 \mathrm{~b}$ \\
\hline$F$ test & $*$ & $* *$ \\
\hline
\end{tabular}

${ }^{1}$ Mean separation in column by the Tukey test at $P \leq 0.05$ for each analyzed variable.

${ }^{2} \mathrm{IW}-1$, intermittent warming at $20^{\circ} \mathrm{C}$ for 48 hours every 7 days and storage at $5^{\circ} \mathrm{C}$; IW-2, intermittent warming at $20^{\circ} \mathrm{C}$ for 48 hours every 14 days and storage at $5^{\circ} \mathrm{C}, \mathrm{AI}-3$, intermittent warming at $38^{\circ} \mathrm{C}$ for 24 hours every 14 days and storage at $5^{\circ} \mathrm{C}$.

ns, **** non significant and $\mathrm{F}$ test significant at $P \leq 0.05$ and 0.01 , respectively .
'Fortune' mandarins showed that IW at $10^{\circ} \mathrm{C}$ for 3 days every 4 days at $2^{\circ} \mathrm{C}$ retarded CI development as compared to constant storage at $2^{\circ} \mathrm{C}$. Favorable effects of IW have also been seen for 'Valencia' orange and 'Clementine' mandarins warmed at $20^{\circ} \mathrm{C}$ during 6 hours every week (Martinez-Javega \& Cuquerella, 1984).

The greatest difficulty in creating optimum conditions with IW storage lies in the need to operate with temperatures, duration and IW frequency that may change from cultivar to cultivar, fruit maturity stage and growing conditions (Artés, 1995).

As a conclusion, IW at $20^{\circ} \mathrm{C}$ for 48 hours every 7 or 14 days reduced CI after 60 days of storage. No injuries due to chilling were observed after 30 days of refrigerated storage in any of the treatments. The occurrence of chilling symptoms depends on both, the temperature itself and the exposure time to this temperature (Wang, 1994). In the present work, the 30-day exposure period at $5^{\circ} \mathrm{C}$ was not enough to induce $\mathrm{CI}$ in fruit and, thus, the temperature of $5^{\circ} \mathrm{C}$ can be used for 'Tahiti' lime during 30 days of cold storage, without risk of CI. The advantage of this storage temperature is the maintenance of the green color of the skin.

\section{ACKNOWLEDGEMENTS}

To the São Paulo State Research Foundation (FAPESP) for financial support and CNPq for fellowship to first author.

\section{REFERENCES}

ARTÉS, F. Revisión: Innovaciones en los tratamientos físicos para preservar la calidad de los productos hortifrutícolas en la posrecolección. II. Tratamientos térmicos cíclicos. Revista Española de Ciencia y Tecnologia de Alimentos, v.35, p.45-64, 1995.

ARTÉS, F.; ESCRICHE, A.J. Intermittent warming reduces chilling injury and decay of tomato fruit. Journal of Food Science, v.59, p.1053-1056, 1994.

ARTÉS, F.; ESCRICHE, A.J.; MARIN, J.G. Treating 'Primofiori' lemons in cold storage with intermittent warming and carbon dioxide HortScience, v.28, p.809-821, 1993.

BALDWIN, E.A. Citrus fruit. In: SEYMOUR, G.B.; TAYLOR, J.E.; TUCKER, G.A. (Ed.) Biochemistry of fruit ripening. London: Chapman \& Hall, 1994. p.255-271.

CHITARRA, M.I.; CHITARRA, A.B. Pós-colheita de frutos e hortaliças: fisiologia e manuseio. Lavras: ESAL; FAEPE, 1990. 320p.

COHEN, E. Commercial use of long-term storage of lemon with intermittent warming. HortScience, v.23, p.400, 1988.

COHEN, E.; SHUALI, M.; SHALOM, Y. Effect of intermittent warming on the reduction of chilling injury of 'Villa Franka' lemon stored at cold temperature. Journal of Horticultural Science, v.58, p.593-598, 1983. COHEN, E.; BEN-YEHOSHUA; S.; ROSENBERGER, I.; SHALON, Y.; SHAPIRO, B. Quality of lemons sealed in high-density polyethylene film during long-term storage at different temperatures with intermittent warming. Journal of Horticultural Science, v.65, p.603-610, 1990.

KADER, A.A.; ARPAIA, M.L. Postharvest handling system: subtropical fruits. In: KADER, A.A. (Ed.) Postharvest technology of horticultural crops. Oakland: University of California, 1992. p.233-240.

KLUGE, R.A.; CANTILlANO, R.F.F.; BILHALVA, A.B. Internal breakdown of 'Santa Rosa' plums stored at different temperature regimes. Revista Brasileira de Agrociência, v.3, p.125-130, 1997. 
KLUGE, R.A.; RODRIGUES, D.S.; MINAMI, K. Intermittent warming of tomatoes: effects upon chilling injury. Horticultura Brasileira, v.16, p.4-6, 1998 b.

KLUGE, R.A.; SCARPARE FILHO, J.A.; JACOMINO, A.P.; PEIXOTO, C.P. Distúrbios fisiológicos em frutos. Piracicaba: FEALQ, 2001. 58p.

KLUGE, R.A.; HOFFMANN, A.; NACHTIGAL, J.C.; BILHALVA, A.B.; FACHINELLO, J.C. Intermittent warming in 'BR-6' peaches cold stored. Pesquisa Agropecuária Brasileira, v.31, p.543-547, 1996.

KLUGE, R.A.; MODOLO, V.A.; JACOMINO, A.P.; SCARPARE FILHO, J.A.; TESSARIOLI NETO, J.; MINAMI, K. Behavior of three vegetable fruits submitted to intermittent warming during cold storage. Scientia Agricola, v.55, p.473-479, 1998a.

McGUIRE, R.G. Reporting of objective colour measurements. HortScience, v.27, p.1254-1255, 1992.

MARTINEZ-JAVEGA, J.M.; CUQUERELLA, J. Factors affecting of Spanish oranges and mandarins. Proceedings of International Society of Citriculture, v.1, p.511-514, 1984.

SHEWFELT, R.L. Stress physiology: a cellular approach to quality. In: SHEWFELT, R.L.; PRUSSIA, S.E. (Ed.) Postharvest handling: a systems approach. New York: Academic Press, 1993. p.257-276.
SCHIRRA, M.; COHEN, E. Long term storage of 'Olinda' oranges under chilling and intermittent warming temperatures. Postharvest Biology and Technology, v.16, p.63-69, 1999.

SINCLAIR, W.B. The biochemistry and physiology of the lemon and other citrus fruits. Oakland: University of California, 1984. 946p.

WANG, C.Y. Approaches to reduce chilling injury of fruits and vegetables. Horticultural Review, v.15, p.63-95, 1993.

WANG, C.Y. Chilling injury of tropical horticultural commodities. HortScience, v.29, p.986-988, 1994.

ZONTA, E.P.; MACHADO, A.A. SANEST - Sistema de análise estatística para microcomputadores (software). Pelotas: UPFEL, 1984.

Received February 26, 2003

Accepted August 26, 2003 